\title{
DINAMIKA ELITE POLITIK LOKAL MENGENAI ISU PENGUASAAN SUMBER DAYA EKONOMI DALAM USULAN PEMEKARAN DAERAH
}

\author{
Hilal Ramdhani \\ Departemen Ilmu Politik, Universitas Indonesia
}

\begin{abstract}
Abstrak
Pemekaran daerah Provinsi walaupun masih dalam moratorium pemerintah pusat, tetap menjadi perhatian bagi elite-elite politik di tingkat lokal. Alasan adanya kesenjangan ekonomi antara pusat pemerintahan Provinsi dengan daerah-daerah lain, kerap menjadi isu yang digunakan oleh elite politik lokal dalam mengupayakan pemekaran daerah Provinsi. Penelitian ini bertujuan untuk mengetahui penggunaan isu penguasaan sumber daya ekonomi yang digunakan oleh elite politik lokal dalam mengusulkan pemekaran daerah. Penelitian ini menggunakan pendekatan kualitatif dengan metode studi kasus, lokasi penelitian yaitu di kawasan Cirebon Raya yang meliputi Kota Cirebon, Kabupaten Cirebon, Kabupaten Indramayu, Kabupaten Kuningan dan Kabupaten Majalengka, teknik penelitian menggunakan wawancara, observasi dan dokumentasi dengan analisis data menggunakan reduksi, penyajian dan penarikan kesimpulan. Hasil menunjukkan bahwa isu penguasaan sumber daya ekonomi dalam upaya pemekaran Provinsi Cirebon mengalami dinamika antar elite antara yang menyetujui dan menolak usulan pemekaran Provinsi Cirebon atas dasar isu penguasaan sumber daya ekonomi untuk kesejahteraan masyarakat, sehingga selama tahun 2009-2019 Provinsi Cirebon belum dapat direalisasikan.
\end{abstract}

Kata Kunci: Elite Politik Lokal, Pemekaran Daerah, Sumber Daya Ekonomi

\begin{abstract}
The division of the province even though it is still in the moratorium of the central government, remains a concern for political elites at the local level. The reason for the economic disparity between the central government of the Province and other regions is often an issue used by the local political elite in pursuing the division of the Province. This study aims to determine the use of the issue of control of economic resources used by local political elites in proposing regional expansion. This research uses a qualitative approach with a case study method, the research location is in the area of Cirebon Raya which includes Cirebon City, Cirebon Regency, Indramayu Regency, Kuningan Regency and Majalengka Regency, research techniques using interviews, observation and documentation with data analysis using reduction, presentation and drawing conclusions. The results show that the issue of control of economic resources in an effort to expand Cirebon Province experiences dynamics between the elites who approve and
\end{abstract}


reject the proposed division of Cirebon Province on the basis of the issue of control of economic resources for the welfare of the community, so that during 2009-2019 the Province of Cirebon could not be realized.

Keywords: Local Political Elite, Regional Expansion, Economic Resources

\section{PENDAHULUAN}

Dinamika politik ialah interaksi dan interdepedensi antar lembaga yang menghasilkan suatu negosiasi di antara lembaga (Nurhasanah dan Lambung, 2018). Dalam penelitian ini dinamika politik ditujukan kepada interaksi dan interdepedensi elite politik di wilayah Kota dan Kabupaten Cirebon, Majalengka, Kuningan dan Indramayu yang digagas oleh P3C dalam membentuk Provinsi Cirebon.

Kasus proses pemekaran Provinsi Cirebon dimulai pada tahun 2009 sampai sekarang, tepatnya ketika pembentukan Provinsi Cirebon dideklarasikan. Sejumlah perwakilan dewan yang datang menyatakan persetujuannya terhadap pembentukan Provinsi Cirebon. Deklarasi dilakukan oleh Presidium Pembentukan Provinsi Cirebon (P3C) di sebuah ballroom hotel di kawasan Jalan Tuparev, Kabupaten Cirebon. Terdapat sekitar 1.000 orang dan seluruh Panitia Pendukung Pembentukan Provinsi Cirebon hadir. Selain itu, juga terlihat perwakilan dari Dewan Perwakilan Rakyat Daerah, antara lain Ketua Dewan Perwakilan Kabupaten Cirebon, Wakil Ketua Dewan Perwakilan Kota Cirebon, Wakil Ketua Dewan Perwakilan Daerah Majalengka dan Ketua Dewan Perwakilan Kabupaten Indramayu. Satu-satunya perwakilan anggota dewan daerah yang tidak hadir di wilayah Cirebon adalah dari Kabupaten Kuningan (Tempo, 2009).

Dinamika politik yang terjadi sampai tahun 2019 belum mampu mewujudkan koalisi di tingkat Kabupaten dan Kota, karena P3C belum mampu mempengaruhi elite politik di Kabupaten Majalengka dan Kabupaten Kuningan untuk bergabung dalam koalisi pembentukan Provinsi Cirebon. Sejak tahun 2009 hanya Kabupaten Indramayu, Kota Cirebon dan Kabupaten Cirebon yang bergabung dalam koalisi untuk membentuk Provinsi Cirebon (Ramdhani dan Subekti, 2020). Dalam kondisi politik seperti itu, maka tidak bisa membentuk 
sebuah provinsi baru karena tidak sesuai dengan ketentuan hukum yang tercantum dalam Pasal 8 Peraturan Pemerintah No. 78 tahun 2007 yang menyatakan minimal harus ada lima kabupaten dan atau kota untuk melakukan pemekaran provinsi.

Dinamika elite politik lokal di tingkat Kota Cirebon, Kabupaten Indramayu, Kabupaten Majalengka, Kabupaten Cirebon dan Kabupaten Kuningan (ciayumajakuning) memunculkan dinamika elite antara kelompok elite yang menyetujui dan menolak pembentukan Provinsi Cirebon.

Elit politik lokal yang menolak pembentukan Provinsi Cirebon yaitu elite politik lokal di Kabupaten Majalengka dan Kabupaten Kuningan. Sutrisno sebagai Bupati Majalengka dua periode yakni 2008-2013 dan 2013-2018 mengingatkan agar para penggagas tidak mengait-ngaitkan Provinsi Cirebon dengan Kabupaten Majalengka. Sutrisno menegaskan bahwa Kabupaten Majalengka akan tetap menjadi bagian dari Provinsi Jawa Barat. Sutrisno juga menyarankan untuk melakukan pemekaran Kabupaten terlebih dahulu, jika jumlah kabupaten yang mendukung pembentukan Provinsi Cirebon dianggap tidak memenuhi syarat (Nastain, 2012).

Aang Hamid Suganda sebagai Bupati Kuningan menolak adanya gagasan dari P3C untuk mewujudkan pemekaran Provinsi Cirebon, karena fokus pada pembangunan di Kabupaten Kuningan. Apabila ada pemekaran Provinsi Cirebon, hal tersebut akan mengganggu dan mengakibatkan terjadinya gejolak di masyarakat. Hal tersebut menandakan bahwa isu pembangunan daerah dan etnisitas dimunculkan oleh elite politik di Kabupaten Kuningan untuk menolak usulan pemekaran Provinsi Cirebon.

Adanya penolakan dari Kabupaten Majalengka dan Kabupaten Kuningan untuk bergabung menjadi bagian dalam koalisi pembentukan Provinsi Cirebon, menandakan terdapat dinamika elite politik yang mengakibatkan belum terwujudnya Provinsi Cirebon. Dampak dinamika elite tersebut memunculkan gagasan untuk melakukan pemekaran dua kabupaten baru, yaitu Kabupaten Indramayu Barat dan Kabupaten Cirebon Timur (Hidayat, 2011).

Elit politik lokal yang menyetujui pembentukan Provinsi Cirebon yaitu elite politik di Kabupaten Indramayu, Kabupaten Cirebon dan Kota Cirebon. 
Tindakan yang dilakukan oleh elite politik lokal yaitu dengan mengadakan kongres pembentukan Provinsi Cirebon, karena merasa dimarginalisasi oleh Pemerintah Daerah Jawa Barat. Segala kebijakan yang menyangkut pembangunan dinilai belum menyentuh daerah Pantura, seperti Cirebon, Indramayu, bahkan Subang dan Karawang. Hasyim Junaedi sebagai Ketua DPRD Kabupaten Indramayu berjanji akan memperjuangkan aspirasi masyarakat Indramayu (DetikNews, 2008).

Berdasarkan kasus pemekaran Provinsi Cirebon, terjadi dinamika elite politik lokal ditunjukkan untuk membuat koalisi politik di tingkat lokal maupun nasional agar dapat membentuk Provinsi Cirebon. Teori elite dalam proses pemekaran daerah, disampaikan oleh Kimura bahwa kasus pemekaran Provinsi menunjukkan apa yang disebut politik perbedaan. Nilai-nilai simultan yang berbeda dapat menjadi dasar untuk membentuk koalisi elite politik (Kimura, 2010). Dengan kata lain, koalisi elite politik dapat dibentuk karena perbedaan, bukan hanya mengesampingkan perbedaan, hal ini sesuai dengan gerakan teritorial atau regional yang terjadi di Indonesia.

Merujuk pada teori Kimura, belum adanya koalisi yang solid di wilayah ciayumajakuning, karena para elite politik di wilayah ciayumajakuning justru mempertajam politik perbedaan tersebut. Hal itu mengakibatkan tidak terwujudnya koalisi elite di tingkat lokal, yang merupakan aspek penting dalam mewujudkan pemekaran provinsi di Indonesia.

Teori Kimura tentang koalisi elite politik lokal juga menyatakan adanya kesamaan mengenai isu yang digunakan oleh elite politik lokal, seperti isu penguasaan sumber daya ekonomi menjadi aspek penting dalam membentuk koalisi elite di tingkat bawah. Penelitian ini fokus untuk memahami dan menganalisis permasalahan isu penguasaan sumber ekonomi di wilayah ciayumajakuning yang memiliki perbedaan pandangan di antara pada elite, sehingga belum terwujudnya Provinsi Cirebon sampai tahun 2020.

Kimura membentuk teori koalisi elite politik lokal dalam pemekaran daerah didasarkan pada penelitian Malesky tentang pemekaran daerah di negara Vietnam dan Filipina, Stuligross tentang separatisme di negara India, Kraxberger 
tentang separatisme di Nigeria dan Simandjuntak yang melakukan penelitian pemekaran daerah di Indonesia (Kimura, 2010).

Pemekaran daerah mungkin tampak seperti ruang lingkup penyelidikan yang relatif sempit. Di Asia Tenggara, negara-negara seperti Vietnam dan Filipina juga telah mengalami fenomena serupa dalam jumlah provinsi baru. Malesky, berpendapat bahwa provinsi-provinsi baru di Vietnam muncul sebagai akibat dari konflik antara konservatif dan reformis di legislatif nasional. Stuligross melihat pembentukan negara-negara baru di India sebagai cara agar partai-partai nasional dapat mengadili konstituen-konstituen baru dalam upaya untuk mendapatkan keuntungan legislatif di tingkat nasional.

Kimura juga merujuk penelitian Kraxberger menguraikan faktor-faktor berbasis identitas yang mengarah pada pembentukan negara-negara baru di Nigeria, yang ia sebut sebagai wadah kewarganegaraan sub nasional. Pada Konteks Indonesia, Kimura merujuk penelitian Simandjuntak tentang fenomena di tingkat kabupaten dan provinsi, banyak penekanan dalam penelitian Simandjuntak yaitu elite lokal pada dasarnya mengkooptasi reformasi kelembagaan baru untuk keuntungan mereka sendiri di tingkat lokal.

Penelitian Kimura merupakan karya terbaru yang menyoroti sifat politis fenomena pemekaran daerah. Kimura menyatakan upaya untuk melakukan pemekaran daerah dilakukan oleh elite politik lokal secara "horizontal" untuk mendapatkan kekuasaan politik di Indonesia yang menganut desentralisasi. Selain upaya politik secara "horizontal", elite politik lokal juga melakukan tindakan politik secara "vertikal" untuk mendapatkan akses kepada elite politik di tingkat nasional. Kasus-kasus komparatif pemekaran provinsi di Indonesia setelah berakhirnya Orde Baru menunjukkan adanya hubungan vertikal di antara para elite politik dalam proses pemekaran daerah.

Konsep koalisi teritorial bergantung pada konsep skala yaitu wilayah dengan ukuran yang berbeda berkoalisi satu sama lain, misalnya koalisi di tingkat nasional dan lokal. Skala koalisi tersebut bersifat dinamis, sehingga politik dapat bersifat vertikal maupun horizontal sepanjang skala koalisi tersebut. Wilayah atau kawasan marginal dapat mengubah diri mereka dari apa yang disebut sebagai 
"ruang ketergantungan" menjadi "ruang keterlibatan" melalui koalisi dengan kelompok-kelompok di tingkat teritorial yang berbeda, di mana isu-isu lokal diberi prioritas kebijakan melalui pembangunan koalisi tersebut.

Koalisi teritorial menjangkau berbagai tingkat administrasi pemerintahan dan dalam prosesnya mencakup hierarki dan hubungan kekuasaan yang berbeda dalam struktur politik. MacKinnon \& Phelps menyoroti koalisi lintas kelas atau lintas-sektoral, koalisi ini mengilustrasikan bagaimana aliansi sering mengabaikan kelompok-kelompok territorial (MacKinnon dan Phelps, 2001). Aktor-aktor utama dalam koalisi lintas-sektoral dalam konteks Indonesia termasuk organisasi masyarakat sipil lokal, elite politik tingkat lokal, elite politik tingkat provinsi, elite politik tingkat nasional, partai politik, dan berbagai lembaga negara seperti kementerian tingkat nasional.

Pada kenyataannya, koalisi teritorial muncul dalam berbagai kasus pembentukan provinsi baru, mereka beroperasi dengan cara yang sangat berbeda (Perkmann, 2007). Terdapat tiga kasus pemekaran daerah, kasus pertama menunjukkan bahwa aktor lokal "ditingkatkan ke atas" untuk menciptakan hubungan dengan kelompok-kelompok nasional. Dalam kasus kedua, aktor nasional tampaknya telah "turun ke bawah" untuk menciptakan aliansi dengan aktor lokal. Kasus ketiga menggambarkan bagaimana aktor-aktor nasional dan lokal bersama-sama mendorong provinsi baru, sehingga menekan kelompok di bagian tengah.

Pada saat terjadi reformasi di tahun 1998, isu yang dimunculkan oleh kelompok elit pemekaran Provinsi Gorontalo yaitu pada dua prinsip, efisiensi dan kesetaraan. Dalam hal efisiensi, pemekaran daerah diharapkan untuk mempromosikan tata kelola yang lebih dekat dengan masyarakat, dengan demikian secara inheren lebih responsif terhadap tuntutan lokal, terutama di sektor sosial seperti kesehatan dan pendidikan. Dari sudut pandang ekonomi, pemekaran daerah dapat mendorong persaingan di antara unit-unit yang berbeda karena perusahaan dan individu akan dapat memilih tempat tinggal berdasarkan kinerja Kota madya tertentu. Kompetisi ini akan mendorong kinerja yang lebih baik (Kimura, 2007). 
Alasan terbentuknya koalisi elite politik lokal di Gorontalo yaitu adanya persamaan nasib atas marginalisasi dari monopoli politik dan ekonomi di Minahasa, kondisi tersebut terjadi sejak zaman pendudukan Belanda sampai Orde Baru. Momentum reformasi 1998, merupakan kesempatan politik bagi Gorontalo untuk melakukan pemekaran daerah Provinsi. Hal tersebut menandakan bahwa isu sejarah politik, marginalisasi politik, ekonomi, pembangunan daerah, penguatan nilai-nilai budaya, etnisitas dan agama menjadi isu yang membuat terbentuknya koalisi elite politik di Gorontalo untuk melakukan pemekaran daerah.

Penelitian ini menggunakan pendekatan kualitatif yang tidak terbatas pada kategori tertentu dalam pengumpulan data. Metode penelitian menggunakan studi kasus bahwa hasil studi kasus adalah generalisasi dari pola kasus khas dari individu, kelompok atau institusi (Nazir, 2011; Ramdhani, 2014). Lokasi penelitian ini adalah Kota Cirebon, Kab. Cirebon, Kab. Indramayu, Kab. Kuningan dan Kab. Majalengka.

Penelitian ini menggunakan wawancara terbuka, observasi, dan dokumentasi sebagai teknik pengumpulan data. Teknik pengumpulan data relevan untuk menjelaskan masalah penelitian karena akan lebih mengeksplorasi. Kemudian, data yang telah diperoleh dianalisis menggunakan reduksi data, penyajian data dan penarikan kesimpulan. Analisis data ini sangat penting untuk mengurutkan data, mempertajam data dan mengkategorikan data sesuai dengan masalah penelitian.

Jenis analisis data dalam penelitian ini adalah analisis isi yang tidak hanya dalam bentuk teks, tetapi juga konteks (White and Marsh, 2006; Hsieh dan Shannon, 2005). Sehingga peneliti melihat hasil wawancara, observasi dan dokumentasi dalam melakukan analisis.

Jenis analisisnya adalah deskriptif yang bertujuan untuk menggambarkan aspek-aspek yang berkaitan dengan dinamika elit politik, dan analisis hasil menggunakan teori Kimura (2010), tentang dinamika elit politik lokal yang membentuk koalisi secara vertikal atau horizontal untuk membuat ekspansi provinsi, sehingga kesimpulan dapat ditarik sebagai kebaruan penelitian. 


\section{PEMBAHASAN}

Pemanfaatan sumber ekonomi merupakan isu penting yang sering dimunculkan oleh elite politik dalam upaya melakukan pemekaran Provinsi di Indonesia (Damanik, dkk, 2020), seperti yang terjadi dalam kasus pemekaran Provinsi Banten, Provinsi Gorontalo, Provinsi Bangka Belitung. Dalam kasus pemekaran Provinsi Bangka Belitung dari Provinsi Sumatera Selatan, menunjukkan adanya kenaikan PAD yang pada awal Provinsi dibentuk memiliki PAD di kisaran Rp 48 miliar dan saat ini sudah mencapai Rp 700 miliar lebih. Realita tersebut menunjukkan bahwa pemekaran Provinsi dapat meningkatkan jumlah PAD yang diterima oleh Provinsi baru hasil pemekaran.

Berbagai kasus pemekaran Provinsi yang dapat meningkatkan jumlah PAD, membuat kelompok elite di wilayah ciayumajakuning memunculkan isu pemanfaatan ekonomi untuk mengusulkan pemekaran Provinsi Cirebon. Sumber ekonomi di wilayah ciayumajakuning sangat besar, bahkan di setiap daerahnya memiliki karakteristik sumber ekonomi yang berbeda. Bahkan, pada saat ini adanya Bandara Internasional Kertajati di Majalengka, kilang minyak di Indramayu dan pelabuhan di Cirebon merupakan sumber ekonomi sangat besar yang berada di kawasan ciayumajakuning.

\section{a. Potensi Ekonomi Wilayah Cirebon Raya}

Ekonomi merupakan aspek penting dalam mengetahui suatu wilayah dapat melakukan pemekaran daerah Provinsi atau tidak, karena hal ini merupakan aspek fundamental dalam membentuk suatu Provinsi baru (Ramdhani, 2020).

Laju pertumbuhan ekonomi sebagai indikator makroekonomi yang bisa menggambarkan perkembangan atau tingkat kinerja ekonomi suatu wilayah (Rustariyuni, 2014). Secara umum pertumbuhan tersebut dapat diukur melalui sebuah besaran laju PDRB atas dasar harga konstan. Besaran tersebut tidak hanya berguna untuk menilai perkembangan output ekonomi suatu wilayah dari waktu ke waktu, namun juga berguna untuk melakukan perbandingan dengan wilayah lain.

Pertumbuhan ekonomi merupakan indikator makro yang sering digunakan sebagai salah satu alat strategi kebijakan bidang ekonomi (Rachmat, 2013), 
demikian pula dalam Rencana Strategis (Renstra) Provinsi serta Kabupaten/Kota yang berada di wilayah Jawa Barat, laju pertumbuhan ekonomi tersebut menjadi salah satu indikator yang sangat penting untuk evaluasi pembangunan. Berkaitan dengan studi ini, maka akan di bahas perkembangan laju pertumbuhan ekonomi kabupaten/kota di wilayah Cirebon Raya.

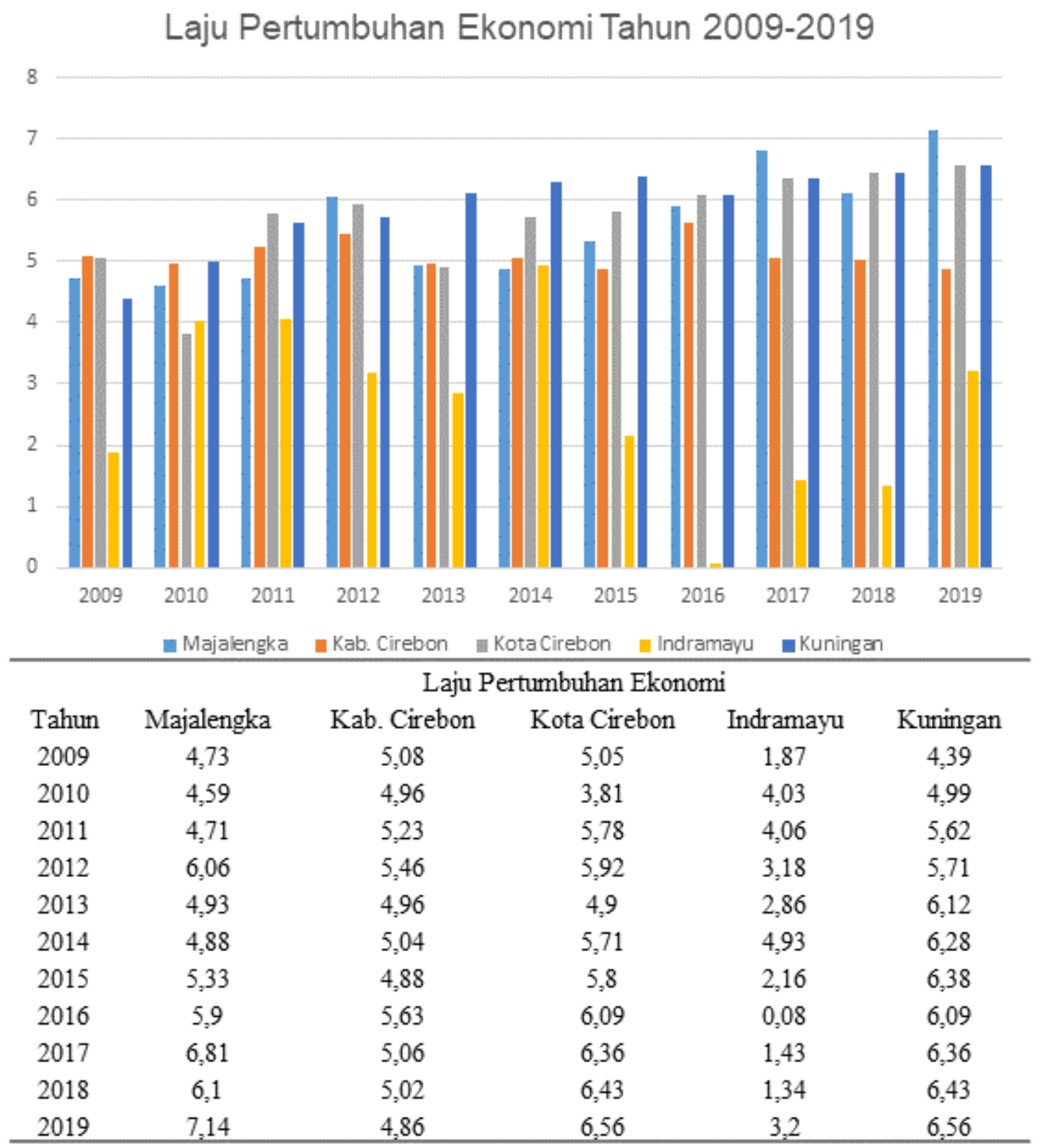

Gambar 1. Data Laju Pertumbuhan Ekonomi

(Data Diolah Peneliti, 2020)

Berdasarkan data tersebut menunjukkan bahwa ada tren peningkatan untuk Kabupaten Kuningan dan Kabupaten Majalengka selama tahun 2009-2019, sedangkan untuk Kabupaten Cirebon dan Indramayu merupakan wilayah dengan 
pertumbuhan ekonomi paling sedikit dibandingkan dengan wilayah lainnya, serta Kota Cirebon yang menunjukkan pertumbuhan ekonomi yang stabil dari tahun 2009-2019.

\section{b. Pandangan Kelompok Elite Politik yang Menyetujui Usulan Pemekaran Provinsi Cirebon}

Isu pemanfaatan sumber ekonomi menjadi isu yang penting bagi elite politik di Kota Cirebon, Kabupaten Cirebon dan Kabupaten Indramayu untuk menyetujui usulan pemekaran Provinsi Cirebon. Isu ekonomi dipandang sebagai sebab keterpurukan ekonomi di wilayah ciayumajakuning, karena pengelolaan sumber ekonomi tidak sepenuhnya dikuasai oleh daerah. Selain itu, penyaluran sumber ekonomi yang kebanyakan lebih fokus pada daerah Priangan, mengakibatkan marginalisasi ekonomi di wilayah ciayumajakuning. Hal ini yang menjadikan elite di Kota Cirebon, Kabupaten Cirebon dan Kabupaten Indramayu mendukung usulan pemekaran Provinsi Cirebon.

Pandangan elite DPRD Kabupaten Cirebon terkait marginalisasi ekonomi oleh Jawa Barat sesuai dengan kondisi yang terjadi di wilayahnya, Elite DPRD Kabupaten Cirebon menganggap bahwa pemanfaatan sumber ekonomi hanya ditujukan untuk pembangunan daerah Priangan. Wilayah ciayumajakuning tidak terlalu diperhatikan oleh Jawa Barat, khususnya untuk Kabupaten Cirebon, peran dari Jawa Barat dalam konteks ekonomi tidak memiliki dampak sama sekali pada kehidupan perekonomian masyarakat. Pernyataan tersebut sangat relevan dengan keadaan perekonomian masyarakat Kabupaten Cirebon yang masih banyak berada dalam kategori masyarakat miskin.

Elite Kabupaten Cirebon pada awal kemunculan isu pemekaran Provinsi Cirebon memberikan dukungan terhadap P3C untuk membentuk Provinsi Cirebon. Alasan ekonomi dijadikan isu penting oleh Elite Kabupaten Cirebon dalam menyetujui usulan pemekaran Provinsi Cirebon, karena memang Kabupaten Cirebon memiliki luas wilayah terbesar di antara wilayah lain di kawasan ciayumajakuning, sedangkan pendapatan asli daerah yang dimiliki Kabupaten Cirebon tidak sesuai dengan besarnya jumlah masyarakat. Dalam konteks tersebut Bupati Kabupaten Cirebon menyetujui usulan pemekaran 
Provinsi Cirebon dengan harapan adanya perbaikan ekonomi di Kabupaten Cirebon.

Di wilayah Indramayu, distribusi sumber ekonomi dari Jawa Barat untuk Kabupaten Indramayu sangat kurang, dibandingkan dengan potensi ekonomi yang dimiliki oleh Kabupaten Indramayu. Daerah Indramayu sampai saat ini masih menjadi daerah yang terpinggirkan di Provinsi Jawa Barat, dibandingkan dengan wilayah Priangan, padahal sumber ekonomi di Indramayu sangat banyak seperti perikanan dan migas. Kurangnya political will Jawa Barat untuk mengembangkan perekonomian di Kabupaten Indramayu mengakibatkan potensi ekonomi yang dimiliki oleh Indramayu tidak dapat dioptimalkan, kondisi tersebut akan dapat diubah bila terjadi pemekaran Provinsi Cirebon, karena pemerintah Provinsi akan lebih dekat secara geografis dengan Kabupaten Indramayu.

Marginalisasi ekonomi Kabupaten Indramayu dapat dilihat dari jalur transportasi publik yang menghubungkan Indramayu dengan Bandung sangat minim, berbeda dengan wilayah-wilayah lain di kawasan ciayumajakuning, seperti Majalengka dan Cirebon. Transportasi yang dapat digunakan menuju Bandung hanya Damri dan Kereta yang rutenya tidak langsung menuju Bandung, sehingga jarak tempuh antara Bandung dan Indramayu cukup lama. Adanya Bandara Internasional Kertajati yang berada di perbatasan antara Majalengka dan Indramayu pun tidak berdampak secara signifikan bagi pertumbuhan ekonomi di Indramayu, karena hanya ada sedikit transportasi dari Bandara Internasional Kertajati ke Kabupaten Indramayu.

Marginalisasi ekonomi yang dihadapi oleh Kabupaten Indramayu sudah terjadi dalam waktu yang lama, sehingga daerah ini terasa dimarginalisasikan oleh Provinsi Jawa Barat. Marginalisasi ekonomi tersebut berdampak pada pertumbuhan ekonomi di Kabupaten Indramayu selam tahun 2016 hanya 0,08\%, ditambah lagi dengan luas wilayah Indramayu yang besar, sehingga muncul usulan untuk melakukan pemekaran Kabupaten Indramayu Barat. Kondisi yang kompleks dari segi ekonomi membuat elite di wilayah Kabupaten Indramayu menjadi elite politik pertama yang menyetujui usulan pemekaran Provinsi Cirebon. Dukungan terkait usulan pemekaran Provinsi Indramayu disampaikan 
oleh elite Kabupaten Indramayu, karena adanya desakan dari masyarakat Indramayu untuk melakukan pemekaran Provinsi Cirebon.

Elit politik DPRD Kota Cirebon menganggap bahwa isu pemanfaatan ekonomi sangat penting dalam mengajukan usulan pemekaran Provinsi Cirebon, karena hal itu merupakan faktor fundamental bagi masyarakat. DPRD Kota Cirebon beranggapan bahwa distribusi ekonomi oleh Jawa Barat belum secara optimal dirasakan oleh wilayah ciayumajakuning, terutama Kabupaten Cirebon dan Kabupaten Indramayu yang memiliki luas wilayah sangat besar dengan pendapatan daerah yang kecil. Permasalahan tersebut dapat diselesaikan melalui pemekaran di tingkat Provinsi dan Kabupaten. Selain itu, keuntungan jika terjadi pemekaran Provinsi Cirebon, maka Kota Cirebon berpotensi menjadi pusat ekonomi dan pusat pemerintahan Provinsi Cirebon, sehingga usulan pemekaran Provinsi Cirebon sangat menguntungkan bagi Kota Cirebon.

Kota Cirebon sebagai pusat kota wilayah ciayumajakuning secara ekonomi sudah mapan, karena dengan luas wilayah dan jumlah penduduk yang kecil dengan pendapatan daerah yang cukup banyak, membuat daerah ini sudah layak menjadi Ibu Kota Provinsi Cirebon. Selain itu, elite DPRD Kota Cirebon menyatakan bila ingin lebih maksimal dalam pemanfaatan sumber ekonomi pemekaran Provinsi Cirebon harus dibarengi dengan pemekaran di tingkat Kabupaten.

Terkait isu pemanfaatan sumber ekonomi, Elite Kota Cirebon mendukung usulan pemekaran Provinsi Cirebon, karena distribusi ekonomi dari Jawa Barat tidak seimbang dengan pendapatan yang diperoleh Jawa Barat dari Cirebon. Kondisi tersebut mengakibatkan sumber daya ekonomi yang seharusnya dapat dioptimalkan oleh wilayah Cirebon, justru tidak dapat dirasakan oleh wilayah Cirebon. Kondisi ini akan berbeda jika terjadi pemekaran Provinsi Cirebon, karena sumber daya ekonomi akan dimanfaatkan langsung oleh pemerintah di wilayah Cirebon.

Presidium Pembentukan Provinsi Cirebon memandang isu pemanfaatan sumber ekonomi sangat penting untuk dijadikan narasi dalam mengupayakan pemekaran Provinsi Cirebon, karena wilayah ciayumajakuning merupakan daerah 
yang memberikan dukungan finansial kepada Jawa Barat paling besar di antara daerah lainnya di Jawa Barat, sedangkan distribusi ekonomi ke wilayah ciayumajakuning sangat minim, sehingga memunculkan marginalisasi ekonomi antara wilayah Priangan dan Pantura. Atas kondisi tersebut sangat relevan untuk melakukan pemekaran Provinsi Cirebon, sehingga pemanfaatan ekonomi wilayah ciayumajakuning benar-benar dimanfaatkan untuk kegiatan ekonomi di wilayah ciayumajakuning.

\section{c. Pandangan Kelompok Elit Politik yang Menolak Pengusulan Pemekaran Provinsi Cirebon}

Isu pemanfaatan sumber ekonomi, dijadikan oleh kelompok elite politik lokal yang menolak usulan pemekaran Provinsi Cirebon untuk tetap menjadi bagian dari Provinsi Jawa Barat. Pandangan tersebut didasarkan pada kesiapan wilayah ciayumajakuning untuk berpisah dengan Provinsi Jawa Barat, hasil kajian yang dilakukan DPRD Majalengka menunjukkan bahwa wilayah ciayumajakuning belum siap secara ekonomi untuk memisahkan diri dengan Jawa Barat, karena Kabupaten Indramayu dan Kabupaten Cirebon memiliki pendapatan daerah yang sangat kecil, hal ini akan berdampak pada permasalahan ekonomi dan kesejahteraan sosial masyarakat.

Pandangan DPRD Majalengka terkait marginalisasi sumber ekonomi oleh Jawa Barat dianggap sangat tidak relevan, karena Jawa Barat justru memperhatikan pertumbuhan ekonomi di wilayah Kabupaten Majalengka, seperti dukungan Provinsi Jawa Barat untuk membangun Bandara Internasional Kertajati, Pembangunan Jalan Tol di Jatitujuh, bahkan dukungan pembangunan pabrikpabrik di wilayah Jatiwangi. Kenyataan tersebut sangat bertentangan dengan isu adanya marginalisasi ekonomi di wilayah ciayumajakuning. Atas dasar itu, Kabupaten Majalengka menolak adanya usulan pemekaran Provinsi Cirebon.

Pernyataan menolak usulan pemekaran Provinsi Cirebon dari DPRD Kabupaten Majalengka juga diperkuat oleh pernyataan Bupati Kabupaten Majalengka, sejak periode kepemimpinan Sutrisno pernyataan terkait penolakan usulan tersebut sudah disampaikan kepada media dan surat kabar, alasannya karena Kabupaten Majalengka sedang berkembang secara ekonomi dan terus 
melakukan pembangunan infrastruktur, hal tersebut dikarenakan adanya dukungan dari Provinsi Jawa Barat. Selain itu, pemekaran Provinsi Cirebon hanya akan menghambat pertumbuhan ekonomi di Kabupaten Majalengka. Sutrisno merasa keberatan jika Kabupaten Majalengka diikutsertakan menjadi bagian daerah yang menyetujui pemekaran Provinsi Cirebon.

Kabupaten Majalengka menjadi prioritas pembangunan Provinsi Jawa Barat, seperti megaproyek Bandara Internasional Kertajati. Jika Kabupaten Majalengka mendukung usulan pemekaran Provinsi Cirebon akan berdampak pada tidak jadinya megaproyek Bandara Internasional Kertajati. Hal itu akan berdampak pada pertumbuhan ekonomi Kabupaten Majalengka di masa yang akan datang, selain itu Kabupaten Majalengka yang tidak memiliki sumber daya alam yang besar, seperti Minyak di Indramayu atau potensi perikanan di Cirebon, sehingga bantuan finansial dari Jawa Barat merupakan hal yang sangat penting dalam proses pembangunan infrastruktur di Kabupaten Majalengka.

Elit di Kabupaten Kuningan menganggap bahwa isu pemanfaatan ekonomi tidak semudah yang diharapkan oleh P3C, dalam kenyataannya daerah hasil pemekaran akan membebani keuangan Provinsi induk dan Pemerintah Pusat. Di khawatirkan nanti akan terjadi sengketa sumber ekonomi yang justru akan menghambat pembangunan di Kabupaten Kuningan, karena saat ini Kabupaten Kuningan sedang fokus membangun ekonomi di sektor pariwisata dan agronomi yang mendapat dukungan dari pemerintah Provinsi Jawa Barat. Bahkan perhatian Jawa Barat pada saat Gubernur Ahmad Heryawan sudah optimal, seperti kunjungan kerja Gubernur pada saat terjadi jalan amblas yang berada Desa Kawah manuk Kecamatan Darma Kabupaten Kuningan.

Dalam konteks tersebut, Elite Kabupaten Kuningan menganggap bahwa Jawa Barat memberikan perhatian kepada Kabupaten Kuningan, sehingga justru jika muncul usulan pemekaran Provinsi Cirebon, hal itu akan menghambat pertumbuhan ekonomi di Kabupaten Kuningan. Selain itu, dikhawatirkan akan terjadi sengketa sumber ekonomi di wilayah ciayumajakuning yang dampaknya akan mengakibatkan instabilitas politik di Kabupaten Kuningan. 


\section{d. Analisis Isu Pemanfaatan Sumber Ekonomi di antara Kelompok Elit Politik}

Pemanfaatan ekonomi merupakan isu penting dalam upaya melakukan pemekaran daerah, karena aspek tersebut merupakan indikator suatu wilayah dapat meningkatkan kesejahteraan atau tidak di masa yang akan datang. Daerah yang dimekarkan harus memiliki PAD yang besar, agar ketika terjadi pemekaran pemerintahan baru tidak mengalami permasalahan dalam bidang keuangan.

Dalam isu pemanfaatan ekonomi di wilayah ciayumajakuning, tidak relevan ketika harus menyatakan bahwa daerah ciayumajakuning termarginalkan secara ekonomi, karena justru pembangunan infrastruktur lebih difokuskan ke daerah ciayumajakuning, seperti jalan Tol, Pelabuhan di Cirebon dan Bandara di Kabupaten Majalengka yang posisinya dekat dengan Kabupaten Indramayu. Dalam konteks tersebut, pemerintah daerah setempat seharusnya lebih dapat mengoptimalkan potensi tersebut untuk menyejahterakan masyarakat dan tidak harus dengan melakukan pemekaran Provinsi dalam waktu yang singkat.

Permasalahan ekonomi di suatu daerah bukan suatu kesalahan pemerintah Provinsi, hal itu lebih pada kinerja pemerintah daerah setempat. Pemerintah Provinsi Jawa Barat sudah melakukan yang terbaik untuk mendistribusikan pemerataan ekonomi di Jawa Barat. Terkait adanya upaya untuk melakukan pemekaran Provinsi Cirebon bukan suatu solusi, akan tetapi lebih baik untuk melakukan pemekaran di tingkat Kabupaten atau Kota.

Sumber daya ekonomi yang ada di wilayah ciayumajakuning memiliki perbedaan pembangunan di antara wilayahnya, saat ini Kabupaten Majalengka dan Kabupaten Kuningan menunjukkan kinerja perekonomian yang terus meningkat. Sedangkan di Kabupaten Indramayu menunjukkan kinerja ekonomi yang rendah. Kondisi tersebut membuat Kabupaten Majalengka dan Kabupaten Kuningan lebih fokus pada pembangunan ekonomi di wilayahnya, daripada melakukan pemekaran Provinsi Cirebon.

Kimura (2010) menyatakan koalisi yang dibentuk oleh elite politik lokal merupakan upaya kelompok individu dan organisasi yang bekerja bersama menuju tujuan bersama. Pada dasarnya elite politik lokal mengkooptasi reformasi 
kelembagaan baru untuk keuntungan mereka sendiri di tingkat lokal. Dalam konteks tersebut pemanfaatan sumber ekonomi menjadi aspek paling strategis yang diambil oleh elite politik lokal. Koalisi yang dibentuk elite politik lokal di wilayah ciayumajakuning pada dasarnya memiliki tujuan untuk memanfaatkan potensi ekonomi secara mandiri.

Isu pemanfaatan ekonomi tampaknya tidak menjadi tujuan bersama para elite politik lokal di wilayah ciayumajakuning untuk melakukan usulan pemekaran Provinsi Cirebon, perbedaan pandangan antara elite politik yang menolak dan menyetujui, secara otomatis membuat koalisi di tingkat lokal tidak dapat terbentuk. Perbedaan pandangan tersebut juga dikarenakan adanya perhatian yang berbeda dari Provinsi Jawa Barat dalam mengembangkan potensi ekonomi di wilayah ciayumajakuning.

Penggerak usulan pemekaran Provinsi Cirebon berasal dari Kabupaten Indramayu yang merupakan wilayah marginal secara ekonomi maupun politik. Dalam teori Kimura, tindakan yang dilakukan oleh elite di Kabupaten Indramayu merupakan tindakan yang sangat strategis dalam koalisi, karena wilayah atau kawasan marginal dapat mengubah diri mereka dari apa yang disebut sebagai "ruang ketergantungan" menjadi "ruang keterlibatan" melalui koalisi dengan kelompok-kelompok di tingkat teritorial yang berbeda, di mana isu-isu lokal diberi prioritas kebijakan melalui pembangunan koalisi tersebut.

Isu-isu marginalitas ekonomi yang dirasakan oleh Kabupaten Indramayu dapat diperjuangkan oleh kelompok elite lainnya, sehingga permasalahan ekonomi yang dirasakan oleh Kabupaten Indramayu mendapatkan dukungan dari elite politik di wilayah lainnya. Hal ini sangat penting bagi Kabupaten Indramayu, untuk dapat menguasai pemanfaatan ekonomi di wilayah Indramayu, seperti Kilang Minyak yang selama ini pendapatannya masuk ke PAD Jawa Barat.

Permasalahan Kabupaten Majalengka dan Kabupaten Kuningan yang tidak menyetujui usulan pemekaran Provinsi Cirebon dan menolak akan adanya isu marginalitas pemanfaatan sumber ekonomi mengakibatkan tidak terbentuknya koalisi elit di tingkat lokal. Hal itu berdampak secara politis maupun hukum, karena secara politis tidak bisa menekan bagian tengah (Provinsi Induk) dan 
secara hukum tidak memenuhi syarat yang terdapat dalam Pasal 8 Peraturan Pemerintah No 78 tahun 2007 tentang tata cara pembentukan, penghapusan, dan penggabungan daerah yang menyebutkan bahwa cakupan wilayah pembentukan provinsi paling sedikit 5 (lima) kabupaten/kota.

Tidak terbentuknya koalisi elite politik di wilayah ciayumajakuning menunjukkan adanya perbedaan dengan teori Kimura bahwa kasus pemekaran provinsi menunjukkan apa yang disebut politik perbedaan. Nilai-nilai simultan yang berbeda dapat menjadi dasar pembentukan koalisi. Dengan kata lain, koalisi dapat bekerja karena adanya perbedaan, bukan justru mengesampingkan perbedaan. Kasus usulan pemekaran Provinsi Cirebon menunjukkan bahwa perbedaan pendapatan daerah dan tingkat ekonomi menjadi alasan bagi elite di Kabupaten Majalengka dan Kabupaten Kuningan menolak usulan pemekaran Provinsi Cirebon, karena dianggap akan berdampak tidak baik bagi daerah hasil pemekaran.

Pandangan elite politik terkait isu pemanfaatan sumber daya ekonomi juga dikarenakan setiap wilayah mendapatkan perlakuan yang berbeda dari Jawa Barat, sehingga terdapat wilayah yang merasa diperlakukan dengan baik oleh Jawa Barat seperti Kabupaten Majalengka dan Kabupaten Kuningan. Begitu pula wilayah yang mendapatkan perlakukan yang tidak optimal, seperti Kabupaten Indramayu dan Kabupaten Cirebon. Perbedaan perasaan marginalitas ekonomi di wilayah ciayumajakuning, berdampak pada pandangan elite politik lokal terkait isu pemanfaatan ekonomi dalam membentuk koalisi elite politik lokal untuk mengusulkan pemekaran Provinsi Cirebon.

Berdasarkan pandangan-pandangan dari para elite politik yang menyetujui pemekaran Provinsi Cirebon, isu pemanfaatan sumber ekonomi sangat penting dalam membentuk koalisi elite politik lokal untuk mengusulkan pemekaran Provinsi Cirebon, perasaan marginalisasi ekonomi selalu menjadi isu strategis dalam membentuk koalisi di tingkat lokal, seperti yang terjadi pada pemekaran di Gorontalo, Banten maupun Kepulauan Riau, isu pemanfaatan ekonomi merupakan pemenuhan dasar kebutuhan masyarakat. 
Penolakan elite di Kabupaten Kuningan dan Kabupaten Majalengka terkait isu ekonomi sangat relevan dengan hasil penelitian yang dilakukan Ratnawati (2010) bahwa daerah-daerah yang dilakukan pemekaran, secara mayoritas mengalami kegagalan dalam pengembangkan ekonomi dan memberikan kesejahteraan kepada masyarakat. Penelitian Akbar (2019) menunjukkan bahwa permasalahan yang terjadi pada proses awal pemekaran daerah dan menyebabkan permasalahan baru pada daerah induk dan daerah pemekaran saat pemekaran telah berlangsung, yaitu tidak adanya dukungan dan kesepakatan yang jelas antara daerah induk dan daerah pemekaran yang dapat menciptakan permasalahan, di antaranya:

1. Sengketa aset antara daerah induk dan daerah pemekaran

2. Perebutan sumber daya alam antara daerah induk dan daerah pemekaran

3. Sengketa pembagian dana perimbangan antara daerah induk dan daerah pemekaran

4. Lambannya proses-proses konsolidasi yang berlangsung didaerah pemekaran, sebab dalam masa transisi, daerah pemekaran kurang mendapatkan dukungan SDM dan infrastruktur dari daerah induk

5. Permasalahan yang timbul akibat tidak tuntasnya proses-proses yang terjadi pada periode pra-pemekaran.

Lebih lanjut, Akbar menyatakan potensi sumber daya dan aset yang ada didaerah berpotensi menjadi rebutan antara daerah induk dan daerah pemekaran. Perebutan terhadap penguasaan sumber daya dan aset daerah sering kali berpotensi konflik yang berbuntut pada tidak maksimalnya pengelolaan dan penggunaan sumber daya dan aset tersebut. Hal ini memberikan gambaran betapa buruknya penataan wilayah daerah-daerah pemekaran dan tidak siapnya mengelola daerah dengan prinsip otonomi.

Sengketa pemanfaatan ekonomi tersebut juga berdampak pada tingkat nasional, sehingga isu pemanfaatan sumber ekonomi ini akan mengalami proses yang panjang dan justru akan menghambat pertumbuhan ekonomi di wilayah ciayumajakuning. Karena pemekaran daerah akan menimbulkan tekanan terhadap 
APBN akibat adanya sejumlah dana yang harus ditransfer kepada pemerintah daerah baru.

Dalam era desentralisasi ini, bentuk dana transfer ini dikenal sebagai dana perimbangan yang terdiri dari Dana Alokasi Umum (DAU), Dana Alokasi Khusus (DAK), serta Dana Bagi Hasil baik bagi hasil pajak maupun bagi hasil sumber daya alam. Aliran dana inilah yang akan ditransfer kepada pemerintah daerah termasuk pemerintah daerah baru berdasarkan kriteria dan formula tertentu. Jumlah DAU daerah pemekaran ini tentunya juga akan mengurangi jumlah DAU yang diterima daerah induk, sehingga memiliki potensi yang besar pula terjadinya degradasi pada pelayanan publik dan penyediaan infrastruktur kepada masyarakat.

Dalam konteks tersebut pemanfaatan sumber daya ekonomi justru menimbulkan berbagai sengketa antara Provinsi hasil pemekaran dan Provinsi induk (Sulistyono, 2014), tampaknya elite politik di Kabupaten Majalengka dan Kabupaten Kuningan lebih berorientasi ke depan dan fokus pada permasalahan yang terjadi akibat pemekaran Provinsi. Sedangkan, elite politik di Kota Cirebon, Kabupaten Cirebon, Kabupaten Indramayu dan Kesultanan lebih fokus pada perolehan pemanfaatan sumber daya tanpa mempertimbangkan sengketa pemanfaatan sumber ekonomi. Dalam konteks tersebut, ketika isu pemanfaatan ekonomi tidak bisa memunculkan narasi bersama di antara elite politik di wilayah ciayumajakuning, maka sulit untuk membentuk koalisi di tingkat lokal untuk mengusulkan pemekaran Provinsi Cirebon.

\section{KESIMPULAN}

Perbedaan pandangan elite politik lokal mengenai isu penguasaan sumber ekonomi di antara elite politik lokal yang menyetujui dan menolak usulan pemekaran daerah berdampak pada tidak terbentuknya koalisi di tingkat bawah untuk mengajukan usulan pemekaran Provinsi Cirebon. Perbedaan pandangan antara elite, tampaknya di dasarkan pada ketidakpercayaan antar elite politik lokal untuk mengelola sumber daya alam yang dimiliki oleh daerah, elite yang menolak usulan pemekaran Provinsi Cirebon lebih percaya sumber daya ekonomi dikelola untuk Provinsi Jawa Barat, karena sampai saat ini belum pernah ada kasus korupsi 
elite di Jawa Barat atas mengelolaan sumber daya ekonomi di wilayah ciayumajakuning.

\section{DAFTAR PUSTAKA}

Akbar, Surya. "Analisa Masalah-Masalah Yang Muncul Dalam Pemekaran Wilayah Baru Pada Penyelengaraan Otonomi Daerah." JIAGANIS 3, no. 1 (2019).

Damanik, K. I., Lubis, E., Siregar, T. R., Nilasari, I., Khairuddin, A., Mufti, N \& Ningsih, S. (2010). Otonomi Daerah, Etnonasionalisme, dan Masa Depan Indonesia: Berapa Persen Lagi Tanah dan Air Nusantara Milik Rakyat. Yayasan Pustaka Obor Indonesia.

DetikNews, "8.000 Orang Berkongres Tuntut Pembentukan Provinsi Cirebon", diakses dari https://news.detik.com/berita/890024/8000-orangberkongres-tuntut-pembentukan-provinsi-cirebon, pada tanggal 06 Februari 2008 pukul 13:56 WIB

Hidayat, Atep Afia "Provinsi Cirebon Berdiri, Provinsi Jawa Barat "Pudar", diakses dari https://www.kompasiana.com/atep_afia/550913b1a33311b4422e3b42/pr ovinsi-cirebon-berdiri-provinsi-jawa-barat-pudar, pada tanggal 6 November 2011 pukul 10:32

Hsieh, Hsiu-Fang, and Sarah E. Shannon. "Three approaches to qualitative content analysis." Qualitative health research 15, no. 9 (2005): 12771288.

Kimura, Ehito. "Marginality and opportunity in the periphery: The emergence of Gorontalo province in North Sulawesi." Indonesia 84 (2007): 71-95.

Kimura, Ehito. "Proliferating provinces: Territorial politics in post-Suharto Indonesia." South East Asia Research 18, no. 3 (2010): 415-449.

MacKinnon, Danny, and Nicholas A. Phelps. "Devolution and the territorial politics of foreign direct investment." Political Geography 20, no. 3 (2001): 353-379.

Nastain, Inin. "Majalengka Ogah Ikut Wacana Provinsi Cirebon”, diakses dari https://news.okezone.com/read/2012/01/28/340/565334/majalengkaogahikut-wacana-provinsi-cirebon, pada tanggal 28 Januari 2012 pukul 23:11 WIB 
Nazir, Muhammad. 2011. Metode Penelitian. Bogor: Ghalia Indonesia

Nurhasanah, Nurhasanah, and Nenie Adriati Lambung. "Analisis Hubungan DPRD Dan Pemerintah Kota Palangka Raya Pada Penyusunan Dan Penetapan Peraturan Tentang APBD." Pencerah Publik 5, no. 1 (2018): $1-9$.

Perkmann, Markus. "Construction of new territorial scales: a framework and case study of the EUREGIO cross-border region." Regional studies 41, no. 2 (2007): 253-266.

Rachmat, Muchjidin. "Nilai tukar petani: Konsep, pengukuran dan relevansinya sebagai indikator kesejahteraan petani." In Forum Penelitian Agro Ekonomi, vol. 31, no. 2, (2013), 111-122.

Ramdhani, Hilal. "Pencegahan White Collar Crime melalui Kebijakan Non Penal." Jurnal Somasi 1, no. 1 (2014): 19-31.

Ramdhani, Hilal, and Valina Singka Subekti. "Dynamic Local Political Elite in Process for Proposing Regional Expansion." JIP (Jurnal Ilmu Pemerintahan): Kajian Ilmu Pemerintahan dan Politik Daerah 5, no. 1 (2020): 1-11.

Ramdhani, Hilal. "Peran Presidium Pembentukan Provinsi Cirebon dalam Proses Pemekaran Provinsi Cirebon." Moderat: Jurnal Ilmiah Ilmu Pemerintahan 6, no. 1 (2020): 1-13.

Ramdhani, Hilal. "Realitas Elit Politik Lokal dan Persepsi Masyarakat dalam Proses Pemekaran Daerah." JPPUMA Jurnal Ilmu Pemerintahan dan Sosial Politik Universitas Medan Area 7, no. 2 (2019): 219-226.

Ratnawati, Tri. "Satu dasa warsa pemekaran daerah Era reformasi: Kegagalan otonomi daerah." Jurnal Ilmu Politik 21 (2010): 122-235.

Rustariyuni, Surya Dewi. "Pengaruh Gini Ratio, Pengeluaran Non Makanan Per Kapita, Belanja Daerah Dan Laju Pertumbuhan Ekonomi Pada Indeks Pembangunan Manusia Kabupaten/Kota Di Provinsi Bali Periode 20042012." Jurnal Piramida 10, no. 1 (2014): 45-55.

Sulistyono, Djoko. "Penyelesaian Sengketa Batas Laut Antara Provinsi Kepulauan Bangka Belitung dengan Provinsi Kepulauan Riau." Jurnal Bina Praja: Journal of Home Affairs Governance 6, no. 2 (2014): 167182. 
Tempo, "Presidium Pembentukan Provinsi Cirebon Deklarasikan Provinsi Cirebon", diakses dari https://nasional.tempo.co/read/163726/presidiumpembentukan-provinsicirebon-deklarasikan-provinsi-cirebon, pada tanggal 29 Oktober 2009 pukul 15:55 WIB

White, Marilyn Domas, and Emily E. Marsh. "Content analysis: A flexible methodology." Library trends 55, no. 1 (2006): 22-45. 